\title{
Plasma cell-free DNA in patients needing mechanical ventilation
}

\author{
Marjatta Okkonen ${ }^{1 *}$, Päivi Lakkisto ${ }^{2,3}$, Anna-Maija Korhonen ${ }^{1}$, Ilkka Parviai-nen ${ }^{4}$, Matti Reinikainen ${ }^{5}$, Tero Varpula ${ }^{1}$,
} Ville Pettilä ${ }^{1}$ and The FINNALI Study Group

\begin{abstract}
Introduction: Concentrations of plasma cell-free DNA are increased in various diseases and have shown some prognostic value in many patient groups, including critically ill patients. Pathophysiological processes behind the need for mechanical ventilation and the treatment itself could raise plasma levels of cell-free DNA. We evaluated levels of plasma cell-free DNA and their prognostic value in patients needing mechanical ventilation.

Methods: We studied prospectively 580 mechanically ventilated critically ill patients. Blood samples were taken at study admission (Day 0) and on Day 2. Plasma cell-free DNA concentrations were measured by real-time quantitative PCR assay for the $\beta$-globin gene and are expressed as genome equivalents (GE)/ml.

Results: Median (interquartile range, IQR) plasma cell-free DNA concentration was $11,853 \mathrm{GE} / \mathrm{ml}$ (5,304 to 24,620 $\mathrm{GE} / \mathrm{mL})$ at study admission, and $11,610 \mathrm{GE} / \mathrm{mL}(6,411$ to $21,558 \mathrm{GE} / \mathrm{mL})$ on Day 2. Concentrations at admission were significantly higher in 90-day non-survivors than survivors, $16,936 \mathrm{GE} / \mathrm{mL}$ (7,262 to 46,866 GE/mL) versus 10,026 GE/ $\mathrm{mL}(4,870$ to $19,820 \mathrm{GE} / \mathrm{mL}), P<0.001$. In a multivariate logistic regression analysis plasma cell-free DNA concentration over $16,000 \mathrm{GE} / \mathrm{ml}$ remained an independent predictor of 90-day mortality (adjusted odds ratio 2.16, 95\% confidence interval Cl 1.37 to 3.40). Positive likelihood ratio of plasma cell-free DNA at admission for the prediction of 90-day mortality was $1.72(95 \% \mathrm{Cl} 1.40$ to 2.11$)$.

Conclusions: Plasma levels of cell-free DNA were significantly higher in non-survivors than survivors. Plasma DNA level at baseline was an independent predictor of 90-day mortality. However, its clinical benefit as a prognostic marker seems to be limited.
\end{abstract}

\section{Introduction}

Cell-free DNA is detected in blood in many diseases, but also in healthy individuals. Cell-free DNA can originate from necrotic cells or apoptotic processes, and active release of DNA fragments from living cells has also been described [1]. The exact mechanism of DNA occurrence in blood, however, is not fully understood. Knowledge about the elimination of cell-free DNA from blood is inadequate [2], but available data suggest that more than one mechanism is involved in its clearance. In a recent meta-analysis, based on 39 studies, cell-free DNA concentrations up to 4,000 genome equivalents $(\mathrm{GE}) / \mathrm{ml}$ in healthy controls were reported [3]. Higher

\footnotetext{
* Correspondence: marjatta.okkonen@hus.fi

'Division of Anaesthesia and Intensive Care Medicine, Department of Surgery, Helsinki University Central Hospital, Haartmaninkatu 4, PO Box 340, 00029 HUS, Helsinki, Finland

Full list of author information is available at the end of the article
}

levels have been measured in different pathophysiological states: in malignancies [4], sepsis [5,6], acute pancreatitis $[7,8]$, trauma [9], stroke [10], myocardial infarction [11], and abdominal pain [12]. Plasma cellfree DNA may have prognostic value in many acute clinical situations: patients with sepsis [6], acute coronary syndrome (ACS) [13], trauma [9], pancreatitis [7], and in patients after cardiac arrest [14].

The need for mechanical ventilation (MV) is a consequence of diverse pathophysiologic conditions of both pulmonary and extrapulmonary origin leading to impaired oxygenation and/or ventilation or a need to secure the airway and support ventilation because of impaired consciousness. Deteriorated oxygenation can per se cause tissue hypoxia and, thus, damage to cells. In addition, pathophysiologic processes leading to the need of MV are potentially accompanied with cell death and the release of DNA to circulation. Furthermore,
C Biomed Central

(c) 2011 Okkonen et al.; licensee BioMed Central Ltd This is an open access article distributed under the terms of the Creative Commons Attribution License (http://creativecommons.org/licenses/by/2.0), which permits unrestricted use, distribution, and reproduction in any medium, provided the original work is properly cited. 
MV itself may cause damage to lung tissue [15] and theoretically induce release of DNA to circulating plasma. Association between injurious ventilation and increased remote organ apoptosis as well as increased type 2 cell necrosis in lungs has been shown in an animal study [16]. However, no large-scale human studies regarding plasma cell-free DNA in patients needing MV have been published.

The aim of our study was to assess plasma cell-free DNA concentrations and their prognostic value on 90day mortality in a large observational multi-centre study on mechanically ventilated critically ill patients.

\section{Materials and methods}

We conducted a prospective, epidemiological cohort study on patients needing MV in 25 Finnish intensive care units (ICU) during an eight-week period (from 16 April to 10 June 2007) (The FINNALI study). In this study we pros-pectively evaluated all patients $(\geq 16$ years) treated in ICUs. The study design and epidemiological results have been published previously [17]. In brief, all patients treated with respiratory support for more than six hours either with invasive or non-invasive interface were included in the study. The local ethics committees approved the study. Informed consent from patients or surrogates was required for laboratory samples.

We registered demographic data, underlying risk factors for the need of MV, physiological and ventilatory data at the study admission, and medications. The clinical report form (CRF) data were reported as an attachment to the Finnish Intensive Care Consortium routine dataset which includes data about reason for admission, severity scorings (Simplified Acute Physiology Score (SAPS) II [18] and Sequential Organ Failure Assessment (SOFA) score [19]), and hospital outcome. Acute lung injury (ALI) and acute respiratory distress syndrome (ARDS) were defined according to the American-European Consensus Conference (AECC) criteria [20]. Patients were divided to those who had infection and those who did not by Acute Physiology and Chronic Health evaluation (APACHE) III, ICD10-diagnoses (International Statistical Classification of Diseases and Related Health Problems), and the presence of pneumonia or sepsis as an underlying risk factor during the preceding 48 hours. Data collection was accomplished with an Internet-based interface. Mortality data were obtained from Statistics Finland [21]. This study is a prospective sub-study evaluating plasma cell-free DNA in the FINNALI cohort.

\section{Blood sampling}

Two blood samples were drawn: first at the time of study inclusion (Day 0, sample A) and second in the morning of Day 2 (sample B) to $10 \mathrm{ml}$ heparin containing tubes. Plasma was separated as soon as possible by centrifugation at $1,500 \mathrm{~g}$ for 15 minutes and transferred to acid-handled plastic tubes, which were stored at a minimum of $-20^{\circ} \mathrm{C}$ in each hospital until the study completion. All samples were collected at Helsinki University Central Hospital and stored at $-80^{\circ} \mathrm{C}$.

\section{Quantification of plasma cell-free DNA}

DNA extraction and quantification of plasma cell-free DNA were performed as described earlier [6,22]. Briefly, plasma samples were centrifuged at $16,000 \mathrm{~g}$ for $10 \mathrm{~min}$ utes before DNA extraction to remove any residual cells [23]. DNA was extracted using the QIAamp DNA Blood Mini Kit (Qiagen, Hilden, Germany) according to the "blood and body fluid protocol", and plasma cell-free DNA was measured by real-time quantitative PCR assay for the $\beta$-globin gene. A 10 -fold serial dilution of human genomic DNA (Roche Diagnostics GmbH, Mannheim, Germany) was used as a standard curve in the PCR assay. Results are expressed as genome equivalents $(\mathrm{GE}) / \mathrm{ml} ; 1 \mathrm{GE}$ equals 6.6 pikograms of DNA. In this study, we considered plasma cell-free DNA concentration of 4,000 $\mathrm{GE} / \mathrm{ml}$ as an upper limit of normal range, value obtained from a recent meta-analysis [3].

\section{Statistics}

Data are presented as median and interquartile ranges (IQR, $25^{\text {th }}$ and $75^{\text {th }}$ percentiles) or numbers and percentages. The primary endpoint was 90-day mortality. For comparisons of non-parametric data between survivors and non-survivors, we used Mann-Whitney U-test. We assessed the differences in plasma cell-free DNA concentrations between different strata according to the severity of oxygenation impairment, as reflected by the baseline $\mathrm{PaO}_{2} / \mathrm{FiO}_{2}$-ratio. We also compared non-pulmonary SOFA scores between these strata to find out whether there was a correlation between impaired oxygenation and failure of other organ systems. We first used the Kruskal-Wallis test and then the post hoc Mann-Whitney test with $P<0.01$ considered as significant due to multiple comparisons. The Spearman's rank correlation test was performed to evaluate the association between plasma DNA at admission, baseline $\mathrm{pH}$, renal SOFA points at Day 1, SAPS II score, baseline $\mathrm{PaO}_{2} / \mathrm{FiO}_{2}$-ratio, and baseline tidal volume per predicted body weight. We analyzed the receiver operating characteristic (ROC) curve for plasma cell-free DNA at admission for 90-day mortality prediction. For calculations of sensitivity, specificity and positive likelihood ratios (with 95\% confidence intervals, CI) of plasma cell-free DNA for prediction of 90-day mortality we used two cutoff points, one obtained from the earlier study [6] and one from the present study by Youden's method [24]. For 
identification of independent predictors of 90-day mortality we performed a multivariate backward logistic regression analysis. Variables included in the analysis were: plasma cell-free DNA over the best cutoff value at admission, present infection, and all variables found to be independent predictors for 90-day mortality in the FINNALI study (SAPS II score minus oxygenation, chronic heart disease, suspected aspiration, intoxication, and baseline $\mathrm{PaO}_{2} / \mathrm{FiO}_{2}$-ratio). We also made another multivariate backward logistic regression analysis with otherwise same variables, but plasma cell-free DNA was included as a categorical variable divided to arbitrary intervals of 5,000 GE/ml. We constructed Kaplan-Meier curves of 90-day survival according to plasma cell-free DNA at admission. Finally, we performed a subgroup analysis excluding cardiac surgery patients and including only patients with an emergency admission and invasive ventilation exceeding 24 hours. We compared the plasma DNA levels of this subgroup to the rest of the study patients by the Mann-Whitney test. In all analyses, $P<0.05$ was considered as significant.

\section{Results}

\section{Study patients}

The study flowchart is presented in Figure 1. Of 958 patients in the FINNALI study, all 580 patients (61\%) with consent given for laboratory samples and at least sample A (at study admission) available were included to this study. Sample A was drawn six hours (median, IQR 6 to 8 hours) and sample B 42 hours (median, IQR 38 to 47 hours) after the start of ventilatory support. Study patients were older (65 vs. 60 yrs.) and more often elective admissions (17 vs. 9\%), but did not differ significantly from the rest of the FINNALI study patients in gender, hospital or 90-day mortality, SAPS II score, SOFA score at 24 hours, operative status, or ventilatory support time (data not shown).

Characteristics of the study patients divided into subgroups are presented in Table 1, and baseline physiological characteristics in Table 2. Predisposing factors for the need of MV among 580 patients were: surgery in 229 (39\%), decreased level of consciousness in 146 (25\%), cardiac insufficiency in 128 (22\%), suspected aspiration in 58 (10\%) and witnessed aspiration in 29 (5\%), sepsis in 82 (14\%), pneumonia in $68(12 \%)$, other respiratory infection in $60(10 \%)$, intoxication in $34(6 \%)$, massive transfusion in $31(5 \%)$, severe trauma in $29(5 \%)$, acute pancreatitis in $20(3 \%)$, and neuromuscular disease in $16(3 \%)$ patients. Invasive ventilation was used in 506 of 580 study patients (87\%). Of 229 postoperative patients, 99 (43\%) were elective admissions, mostly (64 patients, $65 \%$ ) for cardiac surgery. Hospital and 90-day mortalities were 134 (23\%, 95\% CI 20 to $27 \%)$ and 169 (29\%, 95\% CI 25 to 33\%) of the 580 patients, respectively.

\section{Concentrations of plasma cell-free DNA}

In the 580 patients, median (IQR) plasma cell-free DNA concentration was $11,853 \mathrm{GE} / \mathrm{mL}(5,304$ to $24,620 \mathrm{GE} /$ $\mathrm{mL}$ ) in sample $\mathrm{A}$ and $11,610 \mathrm{GE} / \mathrm{mL}(6,411$ to 21,558 $\mathrm{GE} / \mathrm{mL})$ in sample B. Of the 580 patients, $428(82 \%)$ had a plasma cell-free DNA concentration at admission (sample A) that was higher than normal $(4,000 \mathrm{GE} / \mathrm{ml})$. In postoperative patients $(\mathrm{N}=229)$, the median plasma cell-free DNA concentration (IQR) at admission was $11,436 \mathrm{GE} / \mathrm{ml}(5,587$ to $20,379 \mathrm{GE} / \mathrm{ml})$; in non-operative patients $(\mathrm{N}=351)$, the median $(\mathrm{IQR})$ concentration at admission was $12,156 \mathrm{GE} / \mathrm{ml}(4,938$ to $27,292 \mathrm{GE} / \mathrm{ml})(P$ $=0.36)$. The change in plasma cell-free DNA concentration from sample A to sample B was different in postoperative (rising) and non-operative (descending) patients $(P<0.01)$. Non-operative patients with infection $(\mathrm{N}=124)$ had significantly higher plasma cell-free DNA concentration at admission than those without infection $(\mathrm{N}=227)$ : median (IQR) $15,859 \mathrm{GE} / \mathrm{ml}(7,882$ to $32,887 \mathrm{GE} / \mathrm{ml})$ vs. $9,500 \mathrm{GE} / \mathrm{ml}(4,142$ to $23,386 \mathrm{GE} /$ $\mathrm{ml})(P<0.001)$, respectively. In postoperative patients the corresponding values did not differ between patients with infection $(\mathrm{N}=55)$ or without it $(\mathrm{N}=174)$ : median (IQR) $12,560 \mathrm{GE} / \mathrm{ml}(7,278$ to $28,662 \mathrm{GE} / \mathrm{ml})$ vs. 9,595 $\mathrm{GE} / \mathrm{ml}(5,264$ to $19,667 \mathrm{GE} / \mathrm{ml})(P=0.053)$, respectively.

The median (IQR) plasma cell-free DNA concentration at admission was significantly higher in 90-day non-survivors than survivors: $16,936 \mathrm{GE} / \mathrm{mL}(7,262$ to $46,866 \mathrm{GE} / \mathrm{mL})$ vs. $10,026 \mathrm{GE} / \mathrm{mL}(4,870$ to $19,820 \mathrm{GE} /$ $\mathrm{mL})(P<0.001)$. In the sample $\mathrm{B}$ the difference was not significant: median (IQR) $12,157 \mathrm{GE} / \mathrm{mL}(6,722$ to $25,933 \mathrm{GE} / \mathrm{mL}$ ) in 90-day non-survivors vs. 11,556 GE/ $\mathrm{mL}(5,962$ to $19,735 \mathrm{GE} / \mathrm{mL})$ in survivors $(P=0.094)$. The difference at admission was statistically significant in non-operative patients, but not in postoperative patients (Figure 2).

Plasma cell-free DNA concentrations according to baseline $\mathrm{PaO}_{2} / \mathrm{FiO}_{2}$-ratio are presented in Figure 3. Non-pulmonary SOFA scores did not differ between these groups of baseline $\mathrm{PaO}_{2} / \mathrm{FiO}_{2}$-ratio $(P=0.389)$. Patients with a $\mathrm{PaO}_{2} / \mathrm{FiO}_{2}$-ratio lower than $300 \mathrm{mmHg}$ $(\mathrm{N}=356)$ had significantly higher plasma DNA concentrations compared to patients with a $\mathrm{PaO}_{2} / \mathrm{FiO}_{2}$-ratio higher than $300 \mathrm{mmHg}(\mathrm{N}=199)$, median (IQR) 13,381 $\mathrm{GE} / \mathrm{mL}(6,628$ to $27,577 \mathrm{GE} / \mathrm{mL})$ vs. $8,314 \mathrm{GE} / \mathrm{mL}$ $(3,946$ to $19,018 \mathrm{GE} / \mathrm{mL})(P<0.001)$, respectively. Concentrations did not differ between patients with ALI/ ARDS $(\mathrm{N}=47)$ and those without $(\mathrm{N}=533)$ : median (IQR) $13,707 \mathrm{GE} / \mathrm{mL}(7,700$ to $35,596 \mathrm{GE} / \mathrm{mL})$ vs. $11,562 \mathrm{GE} / \mathrm{mL}(5,171$ to $24,130 \mathrm{GE} / \mathrm{mL})(P=0.06)$, respectively. Plasma DNA at admission correlated with a $\mathrm{PaO}_{2} / \mathrm{FiO}_{2}$-ratio at baseline $(P<0.001)$, baseline $\mathrm{pH}(P$ $<0.001)$, renal SOFA score at Day $1(P<0.001)$, and 


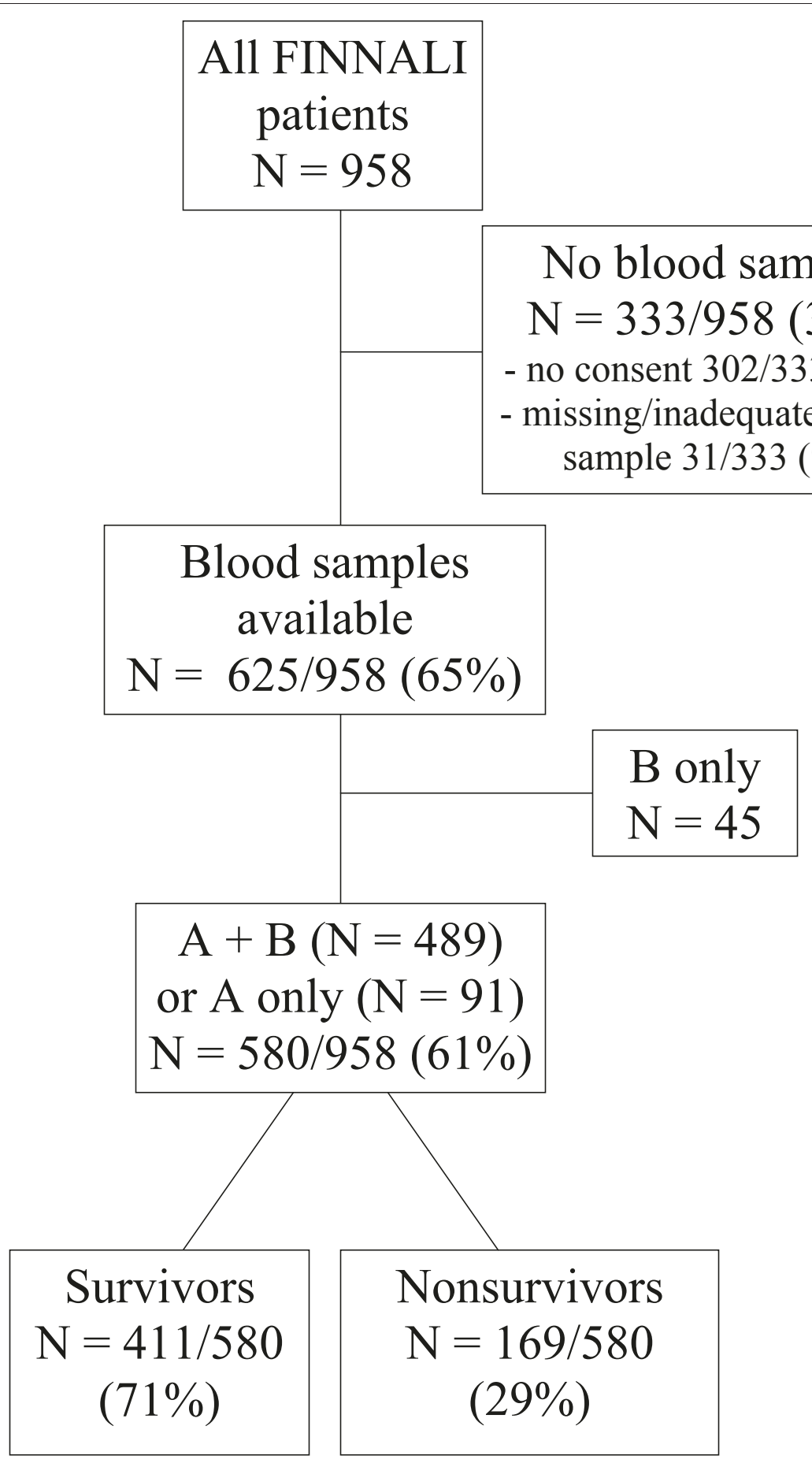

Figure 1 Flowchart of study patients. (A) Blood sample at study admission (Day 0); (B) blood sample at Day 2.

SAPS II score $(P<0.05)$, but not with tidal volume per predicted body weight $(P=0.47)$

\section{Predictive value of plasma cell-free DNA}

The area under the ROC curve (AUC) for plasma cellfree DNA concentration at admission as a predictor of 90-day mortality was 0.624 (95\% CI 0.572 to 0.676 ); for the highest plasma cell-free DNA concentration the AUC was 0.605 (95\% CI 0.552 to 0.657). The AUC was 0.643 (95\% CI 0.581 to 0.704 ) in non-operative patients, 0.571 (95\% CI 0.469 to 0.673 ) in post-operative patients, and 0.609 (95\% CI 0.544 to 0.674$)$ in patients with a 
Table 1 Characteristics of the study patients

\begin{tabular}{lllll}
\hline & $\begin{array}{l}\text { All patients } \\
\mathbf{N}=\mathbf{5 8 0}\end{array}$ & $\begin{array}{l}\text { Postoperative patients } \\
\mathbf{N}=\mathbf{2 2 9}\end{array}$ & Non-operative patients \\
& & & $\begin{array}{l}\text { Infection } \\
\mathbf{N}=\mathbf{1 2 4}\end{array}$ & $\begin{array}{l}\text { No infection } \\
\mathbf{N}=\mathbf{2 2 7}\end{array}$ \\
\hline Age & $61(51,74)$ & $69(56,76)$ & $63(55,73)$ & $62(48,74)$ \\
Male, n (\%) & $382(66)$ & $150(66)$ & $85(69)$ & $147(65)$ \\
SAPS II & $42(30,55)$ & $33(26,46)$ & $42(34,54)$ & $51(36,63)$ \\
SOFA at 24 hours & $8(5,10)$ & $7(5,9)$ & $7(5,10)$ & $8(6,10)$ \\
Max SOFA total & $9(6,12)$ & $9(6,11)$ & $10(6,14)$ & $9(6,12)$ \\
Invasive ventilation, days & $2(1,4)$ & $2(1,4)$ & $2(0,5)$ & $2(1,4)$ \\
Length of stay, ICU, days & $3.2(1.7,6.8)$ & $2.9(1.7,7.1)$ & $5.0(2.6,7.7)$ & $2.7(1.6,5.8)$ \\
Hospital mortality, $n(\%)$ & $134(23)$ & $33(14)$ & $37(30)$ & $64(28)$ \\
90-day mortality, $n(\%)$ & $169(29)$ & $44(19)$ & $44(36)$ & $81(36)$
\end{tabular}

Data are presented in numbers (percentages) or median (interquartile range).

SAPS, Simplified Acute Physiology Score; SOFA, Sequential Organ Failure Assessment; ICU, intensive care unit

baseline $\mathrm{PaO}_{2} / \mathrm{FiO}_{2}$-ratio lower than $300 \mathrm{mmHg}$. The best cut-off value for prediction of 90-day mortality was $16,000 \mathrm{GE} / \mathrm{ml}$. Sensitivity, specificity and positive likelihood ratios of the best cut-off value in plasma cell-free DNA concentration at admission are presented in Table 3 with a comparison to the cut-off value from an earlier study [6].

In the first multivariate analysis, the following factors were independent predictors of 90-day mortality: plasma cell-free DNA concentration over $16,000 \mathrm{GE} / \mathrm{ml}$ at admission $(P=0.001)$, baseline $\mathrm{PaO}_{2} / \mathrm{FiO}_{2}$-ratio $(P=$ $0.004)$, chronic heart disease $(P<0.001)$, and SAPS II score minus oxygenation $(P<0.001)$. The adjusted odds ratio $(95 \% \mathrm{CI})$ for plasma cell-free DNA exceeding $16,000 \mathrm{GE} / \mathrm{ml}$ at admission was 2.22 (1.41 to 3.48) (Table $3)$. In the second multivariate analysis, plasma cell-free DNA divided into intervals of $5,000 \mathrm{GE} / \mathrm{ml}$ was a significant predictor of 90-day mortality $(P=0.001)$. Other variables found to be significant in this second multivariate analysis were the same as in the first analysis.

Kaplan-Meier survival curves for 90-day mortality according to the best cut-off value $(16,000 \mathrm{GE} / \mathrm{mL})$ are presented in Figure 4.

Table 2 Physiological characteristics of the study patients at baseline

\begin{tabular}{ll}
\hline & All patients $(\mathbf{N}=\mathbf{5 8 0})$ \\
\hline $\mathrm{PaO}_{2} / \mathrm{FiO}_{2}$-ratio & $247(172,338)$ \\
Tidal volume/Predicted body weight & $8.6(7.5,9.9)$ \\
PEEP & $6(5,8)$ \\
MAP & $76(67,86)$ \\
$\mathrm{CVP}$ & $9(7,13)$ \\
MV (intubated) & $485(84 \%)$ \\
Vasopressors & $304(52 \%)$ \\
\hline
\end{tabular}

Data are presented in numbers (percentages) or median (interquartile range). CVP, central venous pressure; MAP, mean arterial pressure; MV, mechanical ventilation; PEEP, positive end expiratory pressure
In the subgroup analysis of emergency patients with invasive ventilation exceeding 24 hours $(\mathrm{N}=301)$, the median plasma cell-free DNA (IQR) at admission was $12,034 \mathrm{GE} / \mathrm{ml}(4,924$ to $27,091 \mathrm{GE} / \mathrm{ml})$ vs. $11,642 \mathrm{GE} / \mathrm{ml}$ $(5,636$ to $22,374 \mathrm{GE} / \mathrm{ml})$ in other patients $(\mathrm{N}=279)(P$ $=0.57)$. The AUC for the baseline plasma DNA as a predictor of 90-day mortality in this subgroup was 0.641 (95\% CI 0.573 to 0.708 ).

\section{Discussion}

To our knowledge, this is the largest multi-centre study evaluating plasma cell-free DNA concentrations in critically ill patients. We found that plasma cell-free DNA concentration at admission in mechanically ventilated patients was significantly higher in 90-day non-survivors than survivors. In addition, plasma cell-free DNA at

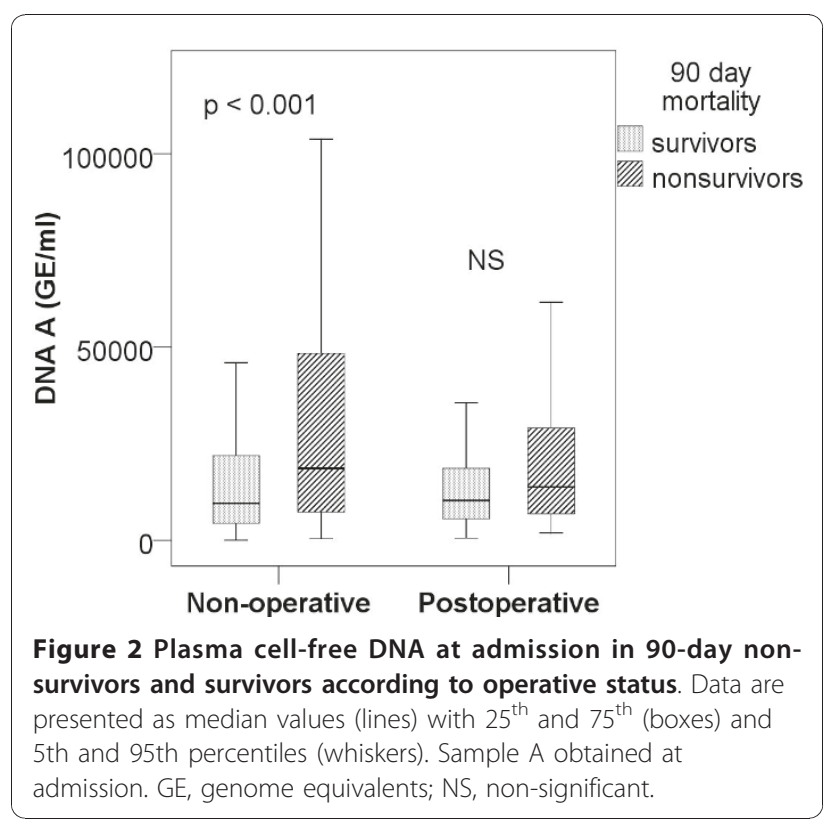




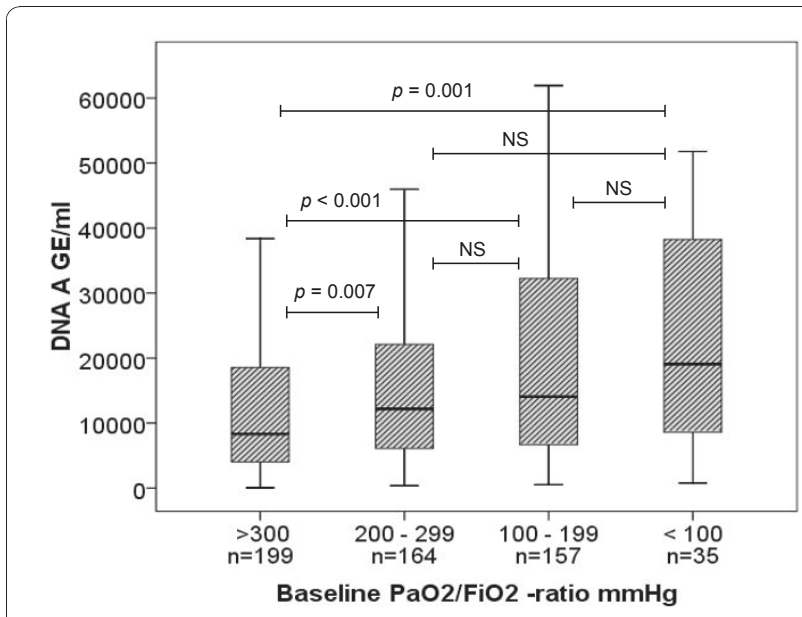

Figure 3 Plasma cell-free DNA at admission according to baseline $\mathrm{PaO}_{2} / \mathrm{FiO}_{2}$-ratio based on SOFA cut-offs. Data are presented as median values (lines) with $25^{\text {th }}$ and $75^{\text {th }}$ percentiles (boxes) and $5^{\text {th }}$ and $95^{\text {th }}$ percentiles (whiskers). Sample A obtained at admission. Comparison between groups by Kruskal-Wallis test ( $P$ $<0.001)$. Post hoc analyses between groups by Mann-Whitney test ( $P<0.01$ considered significant due to multiple comparisons). GE, genome equivalents; NS, non-significant; SOFA, Sequential Organ Failure Assessment

admission over 16,000 GE/ml (and also divided in the increments of $5,000 \mathrm{GE} / \mathrm{ml}$ ) was an independent predictor of 90-day mortality.

In previous studies, concentrations of plasma cellfree DNA have shown wide distribution. This variation may partly be explained by the use of multiple methods in DNA measurements. The problem is evident when exploring values reported in the control groups of healthy individuals [3]. The lack of a standardised method is also a reason why limits of normal values do not exist. Also, overlapping in cell-free DNA concentrations between healthy individuals and patients exists. For example, in the study of Rainer and colleagues, median plasma cell-free DNA concentration has been up to $1,170 \mathrm{GE} / \mathrm{mL}$ in patients with acute coronary syndrome [13], values being at the same level than measured in healthy individuals. In critically ill patients

Table 3 Comparison of two different cut-off points of plasma cell-free DNA for prediction of 90-day mortality

\begin{tabular}{lll}
\hline Cut-off point, GE/ml & $\begin{array}{l}\mathbf{1 2 , 0 0 0} \\
\text { (Saukkonen 2008 [6]) }\end{array}$ & $\begin{array}{l}\mathbf{1 6 , 0 0 0} \\
\text { (present study) }\end{array}$ \\
\hline Sensitivity & $0.60(0.53$ to 0.68$)$ & $0.53(0.45$ to 0.60$)$ \\
Specificity & $0.55(0.50$ to 0.60$)$ & $0.69(0.65$ to 0.74$)$ \\
Positive likelihood ratio & $1.33(1.13$ to 1.57$)$ & $1.72(1.40$ to 2.11$)$ \\
Odds ratio unadjusted & $1.84(1.28$ to 2.65$)$ & $2.52(1.31$ to 4.83$)$ \\
Odds ratio adjusted & $1.39(0.89$ to 2.16$)$ & $2.22(1.41$ to 3.48$)$ \\
\hline
\end{tabular}

Data (at admission) presented with $95 \%$ confidence intervals $\mathrm{GE}$, genome equivalents

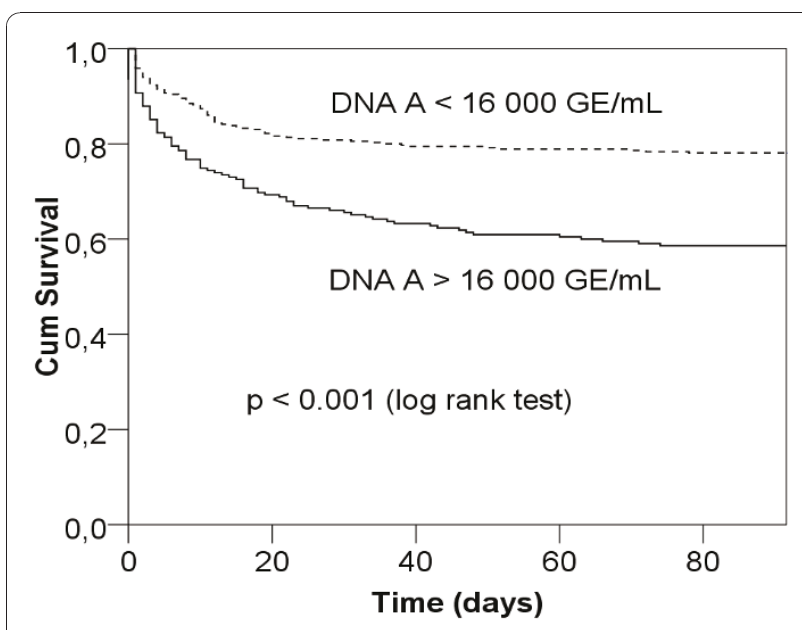

Figure 4 Kaplan-Meier survival curves for 90-day mortality according to plasma cell-free DNA cut-off point at admission.

Sample A obtained at admission. GE, genome equivalents.

with severe sepsis or septic shock, a median plasma cell-free DNA concentration of $8,070 \mathrm{GE} / \mathrm{mL}$ was measured at admission [6], the analyses done in the same laboratory with the same method than in the present study. Patients with major trauma have had median plasma cell-free DNA concentrations over 181,000 GE/ $\mathrm{mL}$ [9]. Kocsis and colleagues have found that levels of plasma cell-free DNA were significantly higher in severe acute pancreatitis than in the mild form of the same disease [8]. In their study, concentrations in the severe form of acute pancreatitis were high (median $989 \mathrm{ng} / \mathrm{ml}(149,848 \mathrm{GE} / \mathrm{mL}))$ as were the concentrations in septic shock (median 3,303 $\mathrm{ng} / \mathrm{ml}(500,454$ $\mathrm{GE} / \mathrm{mL})$ ). In the present study, the median concentration of plasma cell-free DNA at admission was 11,853 $\mathrm{GE} / \mathrm{mL}$, which was markedly lower than the levels in the Kocsis study [8].

In animal studies, isoprenaline has been shown to induce cell death and apoptosis in myocardial and skeletal myocytes in vivo in rats [25]. In clinical situations, adrenergic stress associated with critical illness itself and also catecholamines used may contribute to the release of DNA to circulation. Increased level of plasma DNA has been measured in healthy volunteers after excessive training, possibly reflecting an inflammatory reaction due to anaerobic metabolism [26]. We found a correlation between $\mathrm{pH}$ and plasma DNA at admission, a finding possibly reflecting the severity of illness and/or anaerobic tissue metabolism. A previous study has reported correlation between plasma cell-free DNA and SOFA score as a marker of multiple organ dysfunction and severity of illness [5]. Our results showed positive correlation between plasma DNA and SAPS II score and were consistent with that study. Thus, high levels of 
plasma cell-free DNA can simply be one expression of critical illness regardless of the specific diagnosis.

However, it is also possible that the observed high concentrations of plasma cell-free DNA in our study were caused by impaired oxygenation in particular. We found a correlation between the plasma cell-free DNA concentration and the severity of oxygenation problem (as reflected by the $\mathrm{PaO}_{2} / \mathrm{FiO}_{2}$-ratio) at study inclusion. In general, the lower was the $\mathrm{PaO}_{2} / \mathrm{FiO}_{2}$-ratio, the higher was the plasma cell-free DNA concentration. Moreover, non-pulmonary SOFA scores were comparable in different groups of $\mathrm{PaO}_{2} / \mathrm{FiO}_{2}$-ratio, suggesting the independent effect of impaired oxygenation on plasma cell-free DNA. This association has a physiological rationale as hypoxemia may cause tissue hypoxia and cell death. Unfortunately, we did not measure any other indicators of tissue hypoxia, for example, lactate concentration [27]. A previous study has shown a correlation between plasma cell-free DNA and lactate levels in patients with acute mesenteric ischemia, supporting the connection with tissue hypoxia and plasma DNA concentration [28].

Large tidal volumes are known to associate with the development of lung injury [15]. During the last decade, a lung protective ventilatory strategy with low tidal volumes $(<6 \mathrm{ml} / \mathrm{kg})$ and plateau pressures $(\leq 30$ $\mathrm{cmH}_{2} \mathrm{O}$ ) has been recommended in ALI/ARDS and sepsis [29]. In Finland, these recommendations have been adopted in practise only partly, since tidal volumes have been higher than recommended especially when calculated per predicted body weight (PBW) [17]. In the present study, we did not find a correlation between the plasma cell-free DNA concentration at admission and baseline tidal volume per predicted body weight. Thus, we could not confirm the association with large tidal volume and lung injury using plasma cell-free DNA as a surrogate of lung injury. However, the nature of the present study was observational and not designed to study this association. Neither did we find differences in plasma cell-free DNA concentrations between patients with or without ALI/ARDS. In theory, injured vascular endothelium and alveolar epithelium in ALI and ARDS could raise plasma cell-free DNA. The blood sampling (at admission and on Day 2) may have been too early to find the possible connection with ALI/ARDS, which often develops later. Instead, the concentration of plasma cell-free DNA at admission was significantly higher in patients with infection than without which is in accordance with earlier studies $[5,6]$.

An earlier study found that cell-free DNA is rapidly eliminated from the blood [30]. On the other hand, plasma DNA concentrations have been found to be increased at 96 hours after the end of excessive training in healthy volun-teers, possibly associated with an ongoing inflammatory state [26]. In the present study, plasma samples were taken at two time points, at study inclusion and 36 hours later, and concentrations were at the same level in both samples. This observation may be explained by continuous release of DNA to circulation. The significance of renal function is not fully understood, but in the light of an earlier study, renal function should not affect concentrations [31]. In the present study, we found a correlation between renal SOFA score at Day 1 and plasma DNA at admission. However, in this study we cannot confirm or refute any causality between these factors.

In non-operative patients, concentrations of plasma cell-free DNA were higher in non-survivors than in survivors. In post-operative patients, there was no difference between non-survivors and survivors. One plausible explana-tion is that surgery per se may cause tissue injury that raises plasma cell-free DNA concentrations even when the disease process is not potentially life-threatening. In this study plasma cell-free DNA concentrations of post-operative patients were comparable to those of non-operative patients, despite a remarkably lower severity of illness (SAPS II score) of the postoperative patients. In addition, non-operative patients may have suffered their insult for a longer period of time ago than post-operative patients and, thus, plasma cell-free DNA may be more indicative of cell damage. Rising concentrations of plasma DNA in sample B in post-operative, but not in non-operative patients, suggests this possibility.

We found significantly higher plasma cell-free DNA concentrations at admission in 90-day non-survivors than survivors. A concentration over $16,000 \mathrm{GE} / \mathrm{ml}$, and separately increments of $5,000 \mathrm{GE} / \mathrm{ml}$, were independent predictors of 90-day mortality. However, the AUC for the prediction of 90-day mortality was poor. Furthermore, we found that sensitivity, specificity, and positive likelihood ratio were all lower when used in the group of mechanically ventilated patients than in sepsis patients [6]. In some earlier studies, the predictive value of plasma cell-free DNA has been better $[5,9,10,13]$. However, in these studies follow-up times have varied and the patient numbers may have been inadequate for the prediction of mortality.

\section{Limitations}

Our study has some limitations. First, our cohort of patients was inevitably heterogeneous. As a result, it is possible that some underlying conditions, (for example, occult neoplasia, pregnancy, autoimmune disorders, trauma), may have had an unexpected impact on plasma cell-free DNA values. This heterogeneity is, however, the situation in real life. In addition, the results from the analysis of the subgroup with more severely impaired oxygenation showed that more strict criteria 
did not change the results confirming the robustness of our findings. Second, we measured plasma DNA only at two points, both presumably near the onset of disease. More remote sampling would possibly have provided information about the association to development of ARDS and the healing process. However, our aim was to specifically concentrate on prog-nostication, and, thus, early sampling independent of clinical treatment choices is essential. Finally, the present study is ob-servational by its nature and, thus, could not confirm or refute any causalities.

\section{Conclusions}

In conclusion, we found that plasma cell-free DNA values are commonly high in mechanically ventilated patients. Concentrations measured at admission were higher in 90-day non-survivors than survivors, and predicted indepen-dently 90-day mortality. However, an increased plasma cell-free DNA concentration is neither a sensitive nor a specific predictor of death. Thus, the clinical usefulness of this test seems to be limited.

\section{Key messages}

- Plasma cell-free DNA is commonly increased in patients needing mechanical ventilation.

- Plasma cell-free DNA levels are higher in 90-day non-survivors than survivors.

- However, the predictive value of 90-day mortality in mechanically ventilated patients seems to be poor.

\begin{abstract}
Abbreviations
ACS: acute coronary syndrome; AECC: American-European Consensus Conference; ALI: acute lung injury; APACHE: Acute Physiology and Chronic Health evaluation; ARDS: acute respiratory distress syndrome; GE: genome equivalent; ICD10: International Statistical Classification of Diseases and Related Health Problems; MV: mechanical ventilation; SAPS: Simplified Acute Physiology Score; SOFA: Sequential Organ Failure Assessment
\end{abstract}

\section{Acknowledgements}

We thank all investigators and study nurses in the FINNALI study, and especially laboratory technicians Maritta Putkiranta and Jarkko Lakkisto, for performing DNA analyses. The study was financially supported by EVOgrants T 102010070 and TYH 2008240 from Helsinki University Hospital. FINNALI Study group

Participating hospitals, investigators, and study nurses in alphabetical order: Central Finland Central Hospital: Dr. Raili Laru-Sompa, Tiina Kirkhope, Sirpa Nykänen; East Savo Central Hospital: Dr. Markku Suvela, Sirpa Kauppinen, Anne-Marja Turkulainen; Helsinki University Central Hospital (HUCH) - Jorvi Hospital: Dr. Tero Varpula, Mira Rahkonen; HUCH - Meilahti Hospital ICU: Dr. Anne Kuitunen, Dr. Anna-Maija Korhonen, Dr. Rita Linko, Dr. Marjatta Okkonen, Janne Myller, Jarmo Pekkola, Leena Pettilä, Sari Sutinen; HUCH Meilahti Hospital, Cardiac Surgical ICU: Dr. Raili Suojaranta-Ylinen, Dr. Sinikka Kukkonen, Elina Nurmi-Toivonen; HUCH - Meilahti Hospital, Department of Medicine: Dr. Tom Bäcklund, Dr. Juhani Rossinen, Riina Mäkelä; HUCH - Töölö Hospital: Dr. Janne Reitala, Dr. Jyrki Vuola, Raija Niemi, Marja-Leena Pihlajamaa, Aira Uusipaa-valniemi; HUCH - Surgical Hospital: Dr. Anna-Maria Koivusalo, Pasi Kyllönen; Kanta-Häme Central Hospital: Dr. Risto Puolakka, Tarja Heikkilä, Piia Laitinen; Keski-Pohjanmaa Central Hospital: Dr. Samuli Forsström, Dr. Tadeusz Kaminski, Tuija Kuusela; Kuopio University Hospital: Dr. Esko Ruokonen, Dr. Ilkka Parviainen, Elina Halonen, Sari Rahikainen; Kymenlaakso Central Hospital: Dr. Jussi Pentti, Dr. Seija Alila, Reija Koskinen;
Lappi Central Hospital: Dr. Outi Kiviniemi, Tarja Laurila, Tiina Pikkuhookana; North Karelia Central Hospital: Dr. Matti Reinikainen, Tanja Eiserbeck, Helena Jyrkönen; Oulu University Hospital: Dr. Tero Ala-Kokko, Tarja Lamberg, Sinikka Sälkiö; Päijät-Häme Central Hospital: Dr. Pekka Loisa; Satakunta Central Hospital: Dr. Vesa Lund, Pauliina Perkola, Päivi Tuominen; Seinäjoki Central Hospital: Dr. Kari Saarinen, Dr. Matti Viitanen, Niina Siirilä, Johanna Soini; South Karelia Central Hospital: Dr. Seppo Hovilehto, Dr. Anne Kirsi, Dr. Pekka Tiainen, Sanna Asikainen; South Savo Central Hospital: Dr. Heikki Laine, Pekka Kettunen, Kirsi Reponen; Tampere University Hospital: Dr. Sari Karlsson, Dr. Jyrki Tenhunen, Anna-Liina Korkala, Samuli Kortelainen, Sanna Mäkinen, Minna-Liisa Peltola; Turku University Hospital: Dr. Juha Perttilä, Dr. Olli Arola, Dr. Outi Inkinen, Dr. Erkki Kentala, Jutta Kotamäki; Vaasa Central Hospital: Dr. Pentti Kairi

\section{Author details}

${ }^{1}$ Division of Anaesthesia and Intensive Care Medicine, Department of Surgery, Helsinki University Central Hospital, Haartmaninkatu 4, PO Box 340, 00029 HUS, Helsinki, Finland. ${ }^{2}$ Department of Clinical Chemistry, Helsinki University Central Hospital, Haartmaninkatu 4, PO Box 340, 00029 HUS, Helsinki, Finland. ${ }^{3}$ Minerva Research Institute, BIOMEDICUM Helsinki 2U, Tukholmankatu 8, 00290 Helsinki, Finland. ${ }^{4}$ Division of Intensive Care, Kuopio University Hospital, Puijonlaaksontie 2, PO Box 1777, 70211 Kuopio, Finland. ${ }^{5}$ Department of Intensive Care, North Karelia Central Hospital, Tikkamäentie 16, 80210 Joensuu, Finland.

\section{Authors' contributions}

$\mathrm{MO}$ participated in the study design and data collection, analysed data, and drafted and revised the manuscript. PL carried the responsibility for the laboratory method and analysis, and participated in manuscript writing. AMK, IP and MR were involved in data collection and helped in the manuscript writing. TV conceived the study design and helped in the manuscript writing. VP conceived the study design, advised in the statistical analyses and in the manuscript writing. All authors have contributed intellectually to the content of the manuscript and read and approved the final version.

\section{Competing interests}

The authors declare that they have no competing interests.

Received: 14 January 2011 Revised: 8 July 2011

Accepted: 12 August 2011 Published: 12 August 2011

\section{References}

1. Stroun M, Lyautey J, Lederrey C, Olson-Sand A, Anker P: About the possible origin and mechanism of circulating DNA apoptosis and active DNA release. Clin Chim Acta 2001, 313:139-142.

2. Jung K, Fleischhacker M, Rabien A: Cell-free DNA in the blood as a solid tumor biomarker-a critical appraisal of the literature. Clin Chim Acta 2010, 411:1611-1624.

3. van der Vaart M, Pretorius PJ: Is the role of circulating DNA as a biomarker of cancer being prematurely overrated? Clin Biochem 2010, 43:26-36.

4. Gormally $E$, Caboux $E$, Vineis $P$, Hainaut $P$ : Circulating free DNA in plasma or serum as biomarker of carcinogenesis: practical aspects and biological significance. Mutat Res 2007, 635:105-117.

5. Rhodes A, Wort SJ, Thomas H, Collinson P, Bennett ED: Plasma DNA concentration as a predictor of mortality and sepsis in critically ill patients. Crit Care 2006, 10:R60.

6. Saukkonen K, Lakkisto P, Pettila V, Varpula M, Karlsson S, Ruokonen E, Pulkki K: Cell-free plasma DNA as a predictor of outcome in severe sepsis and septic shock. Clin Chem 2008, 54:1000-1007.

7. Gornik I, Wagner J, Gasparovic V, Lauc G, Gornik O: Free serum DNA is an early predictor of severity in acute pancreatitis. Clin Biochem 2009, 42:38-43.

8. Kocsis AK, Szabolcs A, Hofner P, Takacs T, Farkas G, Boda K, Mandi Y: Plasma concentrations of high-mobility group box protein 1 , soluble receptor for advanced glycation end-products and circulating DNA in patients with acute pancreatitis. Pancreatology 2009, 9:383-391.

9. Lo YM, Rainer TH, Chan LY, Hjelm NM, Cocks RA: Plasma DNA as a prognostic marker in trauma patients. Clin Chem 2000, 46:319-323. 
10. Rainer TH, Wong LK, Lam W, Yuen E, Lam NY, Metreweli C, Lo YM: Prognostic use of circulating plasma nucleic acid concentrations in patients with acute stroke. Clin Chem 2003, 49:562-569.

11. Chang CP, Chia RH, Wu TL, Tsao KC, Sun CF, Wu JT: Elevated cell-free serum DNA detected in patients with myocardial infarction. Clin Chim Acta 2003, 327:95-101.

12. Rainer TH, Chan AK, Lee LL, Yim WW, Lam NY, Yeung SW, Graham CA, Lo DY: Use of plasma DNA to predict mortality and need for intensive care in patients with abdominal pain. Clin Chim Acta 2008, 398:113-117.

13. Rainer TH, Lam NY, Man CY, Chiu RW, Woo KS, Lo YM: Plasma beta-globin DNA as a prognostic marker in chest pain patients. Clin Chim Acta 2006, 368:110-113.

14. Arnalich F, Menendez M, Lagos V, Ciria E, Quesada A, Codoceo R, Vazquez JJ, Lopez-Collazo E, Montiel C: Prognostic value of cell-free plasma DNA in patients with cardiac arrest outside the hospital: an observational cohort study. Crit Care 2010, 14:R47.

15. Gajic O, Frutos-Vivar F, Esteban A, Hubmayr RD, Anzueto A: Ventilator settings as a risk factor for acute respiratory distress syndrome in mechanically ventilated patients. Intensive Care Med 2005, 31:922-926.

16. Imai $Y$, Parodo J, Kajikawa O, de Perrot M, Fischer S, Edwards V, Cutz E, Liu M, Keshavjee S, Martin TR, Marshall JC, Ranieri VM, Slutsky AS: Injurious mechanical ventilation and end-organ epithelial cell apoptosis and organ dysfunction in an experimental model of acute respiratory distress syndrome. JAMA 2003, 289:2104-2112.

17. Linko R, Okkonen M, Pettila V, Perttila J, Parviainen I, Ruokonen E, Tenhunen J, Ala-Kokko T, Varpula T: Acute respiratory failure in intensive care units. FINNALI: a prospective cohort study. Intensive Care Med 2009, 35:1352-1361.

18. Le Gall JR, Lemeshow S, Saulnier F: A new Simplified Acute Physiology Score (SAPS II) based on a European/North American multicenter study. JAMA 1993, 270:2957-2963.

19. Vincent JL, Moreno R, Takala J, Willatts S, De Mendonca A, Bruining H, Reinhart CK, Suter PM, Thijs LG: The SOFA (Sepsis-related Organ Failure Assessment) score to describe organ dysfunction/failure. On behalf of the Working Group on Sepsis-Related Problems of the European Society of Intensive Care Medicine. Intensive Care Med 1996, 22:707-710.

20. Bernard GR, Artigas A, Brigham KL, Carlet J, Falke K, Hudson L, Lamy M, Legall JR, Morris A, Spragg R: The American-European Consensus Conference on ARDS. Definitions, mechanisms, relevant outcomes, and clinical trial coordination. Am J Respir Crit Care Med 1994, 149:818-824.

21. Statistics Finland. [http://www.stat.fi].

22. Saukkonen K, Lakkisto P, Varpula M, Varpula T, Voipio-Pulkki LM, Pettila V, Pulkki K: Association of cell-free plasma DNA with hospital mortality and organ dysfunction in intensive care unit patients. Intensive Care Med 2007, 33:1624-1627.

23. Swinkels DW, Wiegerinck E, Steegers EA, de Kok JB: Effects of bloodprocessing protocols on cell-free DNA quantification in plasma. Clin Chem 2003, 49:525-526.

24. Youden WJ: Index for rating diagnostic tests. Cancer 1950, 3:32-35.

25. Goldspink DF, Burniston JG, Ellison GM, Clark WA, Tan LB: Catecholamineinduced apoptosis and necrosis in cardiac and skeletal myocytes of the rat in vivo: the same or separate death pathways? Exp Physiol 2004, 89:407-416.

26. Fatouros IG, Destouni A, Margonis $K$, Jamurtas AZ, Vrettou C, Kouretas $D$ Mastorakos G, Mitrakou A, Taxildaris K, Kanavakis E, Papassotiriou I: Cell-free plasma DNA as a novel marker of aseptic inflammation severity related to exercise overtraining. Clin Chem 2006, 52:1820-1824.

27. Nichol AD, Egi M, Pettila V, Bellomo R, French C, Hart G, Davies A, Stachowski E, Reade MC, Bailey M, Cooper DJ: Relative hyperlactatemia and hospital mortality in critically ill patients: a retrospective multicentre study. Crit Care 2010, 14:R25.

28. Arnalich F, Maldifassi MC, Ciria E, Quesada A, Codoceo R, Herruzo R, GarciaCerrada C, Montoya F, Vazquez JJ, Lopez-Collazo E, Montiel C: Association of cell-free plasma DNA with perioperative mortality in patients with suspected acute mesenteric ischemia. Clin Chim Acta 2010, 411:1269-1274.

29. Dellinger RP, Carlet JM, Masur H, Gerlach H, Calandra T, Cohen J, GeaBanacloche J, Keh D, Marshall JC, Parker MM, Ramsay G, Zimmerman JL, Vincent $J$, Levy MM: Surviving Sepsis Campaign guidelines for management of severe sepsis and septic shock. Crit Care Med 2004, 32:858-873.
30. Lo YM, Zhang J, Leung TN, Lau TK, Chang AM, Hjelm NM: Rapid clearance of fetal DNA from maternal plasma. Am J Hum Genet 1999, 64:218-224.

31. Garcia Moreira V, de la Cera Martinez T, Gago Gonzalez E, Prieto Garcia B, Alvarez Menendez FV: Increase in and clearance of cell-free plasma DNA in hemodialysis quantified by real-time PCR. Clin Chem Lab Med 2006, 44:1410-1415.

doi:10.1186/cc10357

Cite this article as: Okkonen et al:: Plasma cell-free DNA in patients needing mechanical ventilation. Critical Care 2011 15:R196.

\section{Submit your next manuscript to BioMed Central and take full advantage of:}

- Convenient online submission

- Thorough peer review

- No space constraints or color figure charges

- Immediate publication on acceptance

- Inclusion in PubMed, CAS, Scopus and Google Scholar

- Research which is freely available for redistribution

Submit your manuscript at www.biomedcentral.com/submit
Biomed Central 